\title{
Brown adipose tissue: endocrine determinants of function and therapeutic manipulation as a novel treatment strategy for obesity
}

\author{
Narendra L Reddy ${ }^{1,2 \dagger}$, Bee K Tan ${ }^{1,3 \dagger}$, Thomas M Barber ${ }^{1,2+}$ and Harpal S Randeva $a^{1,2^{*}+}$
}

\begin{abstract}
Introduction: Recent observation of brown adipose tissue (BAT) being functional in adult humans provides a rationale for its stimulation to increase energy expenditure through 'adaptive thermogenesis' for an anti-obesity strategy. Many endocrine dysfunctions are associated with changes in metabolic rate that over time may result in changes in body weight. It is likely that human BAT plays a role in such processes.

Review: In this brief review article, we explore the endocrine determinants of BAT activity, and discuss how these insights may provide a basis for future developments of novel therapeutic strategies for obesity management. A review of electronic and print data comprising original and review articles retrieved from PubMed search up to December 2013 was conducted (Search terms: brown adipose tissue, brown fat, obesity, hormone). In addition, relevant references from the articles were screened for papers containing original data.

Conclusion: There is promising data to suggest that targeting endocrine hormones for BAT modulation can yield a cellular bioenergetics answer for successful prevention and management of human obesity. Further understanding of the physiological link between various endocrine hormones and BAT is necessary for the development of new therapeutic options.
\end{abstract}

Keywords: Brown adipose tissue, Obesity, Hormone

\section{Introduction}

According to the World Health Organization (WHO) report, worldwide obesity rates have more than doubled since 1980. Global figures from 2008 showed that 1.5 billion adults were overweight and that obesity affected 200 million men and 300 million women, with the numbers expected to rise exponentially [1]. Obesity is associated with significant morbidity and mortality that result from the related complications of type 2 diabetes mellitus (T2DM), non-alcoholic fatty liver disease, cardiovascular events, obstructive sleep apnoea, musculoskeletal and psychiatric diseases, and various malignancies [2]. In 2010,

\footnotetext{
* Correspondence: Harpal.Randeva@warwick.ac.uk

${ }^{\dagger}$ Equal contributors

${ }^{1}$ Clinical Sciences Research Laboratories, Division of Metabolic and Vascular Health, Warwick Medical School, University of Warwick, University Hospitals Coventry and Warwickshire, Clifford Bridge Road, Coventry CV2 2DX, UK

${ }^{2}$ Warwickshire Institute for Study of Diabetes, Endocrinology and Metabolism, University Hospitals Coventry and Warwickshire NHS Trust, Clifford Bridge Road, Coventry CV2 2DX, UK

Full list of author information is available at the end of the article
}

overweight and obesity were estimated to cause 3.4 million deaths, $3.9 \%$ of years of life lost, and $3.8 \%$ of disabilityadjusted life-years (DALYs) worldwide [3]. Obesity, in 1980's was limited to affluent countries such as North America, Western Europe and Australasia, but now manifests as a true pandemic, with its increasing prevalence in developing countries such as India, China and Brazil, and spreading even to sub-Saharan Africa [4,5], placing an enormous financial burden on the global economy.

The management of obesity through lifestyle is notoriously difficult and the resulting effects on weight are variable and often transient. Weight regain following weight loss is common and results from a number of mechanisms that redress any loss of energy storage capacity. Such mechanisms include changes in the levels of appetite-regulating hormones following weight loss that encourage weight recovery [6]. Weight loss also reduces energy expenditure [7] and brown adipose tissue (BAT) activity, and this combined with enhanced appetite promotes weight regain. Current therapeutic options for obesity management are 
limited following recent withdrawals of sibutramine and rimonabant amid safety concerns, and problems relating to the supply, unacceptable side-effect profile and longterm efficacy of orlistat [8]. Despite its effectiveness as a weight-loss intervention, bariatric surgery is only applicable to a sub-group of obese patients who meet funding criteria and as such, does not represent a practical solution to the global obesity epidemic [9]. Given the limitations of current therapies, the current global obesity epidemic and escalating incidence of obesity-related deaths, it is imperative to identify novel and effective therapeutic options for obesity.

Obesity results when energy intake exceeds expenditure chronically. Therapeutic strategies for obesity have mainly targeted caloric restriction through central appetite suppression and inhibition of fat absorption [10]. Compared with those acting on central appetite regulation, therapies acting peripherally may prove beneficial whilst causing fewer harmful effects [11]. The body is, by default, genetically predisposed to store energy in preparation for prolonged periods of starvation [12]. Even minor weight-loss through appetite suppression is often redressed through multiple peripheral counterregulatory mechanisms to maintain 'isoenergetic' conditions [6]. Centrally acting drugs can potentially cause adverse psychotropic side effects through cross-reactivity with a variety of other receptors within complex central circuits (such as the endocannabinoid receptor blocker, Rimonabant) [10]. The concept of increasing energy expenditure through therapeutic manipulation of peripheral mechanisms is therefore attractive and worthy of focused research and development.

The main physiological function of BAT, to generate heat for the organism to protect against development of hypothermia, has been well understood for nearly 50 years [13]. Recent studies using ${ }^{18}$ fluoro-labelled 2-deoxyglucose (FDG) positron emission tomography computed tomography (PET-CT) have demonstrated the presence of BAT depots in the axillary, paravertebral, supraclavicular and cervical regions in adult humans [14-16]. Data from various animal studies have demonstrated that through BAT activation, triglyceride stores within white adipose tissue (WAT) can be utilized for heat generation through modulation of adaptive thermogenesis [17]. Therapeutic manipulation of human BAT therefore represents a novel mechanism to promote weight-loss. It is noted that endocrine disorders such as phaeochromocytoma and thyrotoxicosis play a role in activating BAT [18,19]. To maximize its future therapeutic potential, it is important to appreciate the mechanisms by which endocrine dysfunction influences human BAT activity. In this brief review article, we explore the main mechanisms linking various endocrine hormones and human energy expenditure, mediated by effects on BAT activity.

\section{BAT energetics}

There are two main types of adipose tissue, white adipose tissue (WAT) and BAT that have evolved for completely different purposes: to survive famine and prevent hypothermia respectively. WAT and BAT, as energy storage and thermogenic tissues respectively, therefore evolved to protect mammalian organisms from important environmental threats, including lack of food and exposure to cold climates [20]. In addition to WAT and BAT, a third intermediate-type of adipose tissue that is termed 'beige' has recently been identified. Adipocytes from beige adipose tissue (BeAT) depots resemble white adipocytes but possess the classical properties of brown adipocytes. Partial success noted in animal models in converting WAT to BeAT, has set a tone in BAT research field to replicate the concept in humans too $[21,22]$. The characteristic features of WAT, BAT and BeAT, and the origin of BAT are shown in Table 1 and Figure 1 respectively.

Heat production plus external work account for the average daily metabolic rate or total energy expenditure (TEE). TEE can be classically divided into resting metabolic rate (RMR; normally 55-65\% of TEE), activity related energy expenditure (AEE; normally 25-35\% of TEE), and dietinduced thermogenesis (DIT) (about 10\% of TEE) [23,24]. Alternative classification is obligatory energy expenditure, which includes RMR, involuntary AEE and obligatory part of DIT, and facultative energy expenditure, which includes voluntary AEE, cold-induced non-shivering thermogenesis (NST), cold-induced shivering thermogenesis, and facultative part of DIT [23].

Cold-induced activation of BAT has resulted in a high incidence $(60 \%$ to $96 \%)$ of detection as shown in recent PET studies [25,26]. The presence of the $32 \mathrm{kDa}$ uncoupling protein-1 (UCP1) in BAT mitochondria enables heat dissipation rather than generation of adenosine triphosphate (ATP) [27], thereby resulting in non-shivering thermogenesis (NST). Although controversial, BAT is thought to influence DIT through sympathetic nervous system activity via UCP1 $[27,28]$. Using PET studies with radio-labeled fatty acid tracers, Ouellet et al. quantified BAT oxidative metabolism, glucose and non-esterified fatty acid (NEFA) turnover in 6 healthy human subjects, demonstrating unequivocally that BAT contributes to energy expenditure in humans [29]. Extrapolating rodent experiments of thermogenic potential of BAT $(300 \mathrm{~W} / \mathrm{kg})$, Rothwell and Stock calculated that 40-50 g of BAT in humans, might account for $20 \%$ of total energy expenditure [30]. Human PET studies estimated that maximal activation of $63 \mathrm{~g}$ of BAT would result in $4.1 \mathrm{~kg}$ of weight loss during one year [14]. Two independent but congruent human studies estimated an energy expenditure of $200-400 \mathrm{kcal} /$ day, a 10 to $20 \%$ rise in daily basal metabolic rate through BAT activation [31,32]. Therefore, the glucose disposal [33] and triglyceride clearance 
Table 1 Morphological features of BAT, WAT and BeAT

\begin{tabular}{llll}
\hline & WAT & BAT & BeAT \\
\hline Cell shape & Variable, but classically spherical & Polygonal & Resembles WAT \\
Cell size & Variable, but large $(25-200 \mu \mathrm{m})$ & Comparatively small $(15-60 \mu \mathrm{m})$ & Variable \\
Nucleus & Peripheral, flattened & Central, round or oval in shape & To be determined \\
Cytoplasm & Thin, peripheral rim & Large volume evenly distributed throughout cell & To be determined \\
Lipid content & Single large droplet occupying & Multiple small lipid droplets & To be determined \\
Mitochondria & up to 90\% of cell volume & & Intermediate \\
Endoplasmic reticulum (ER) & Lew & Abundant & To be determined \\
& and smooth ER & Present, but poorly developed & To be determined \\
Tissue organization & Small lobules of densely packed cells & Lobular, gland-like & Few other cell types \\
Cell content & Multiple other cell types present & Few other cell types present & present \\
Vascularity & Adequate & Highly vascularised & To be determined \\
Gene expression & PPAR-gamma, aP2, Adiponectin, & UCP-1, PGC-1alpha, $\beta$-3 adreno receptor & Low UCP1, but activated \\
Cell markers & adipsin, perilipin & (ARB3), PRDM16, de-iodinase type II (D2) & by cAMP stimulation \\
\hline & CD34, ABCG2, ALDH & EVA1, EBF3, FBXO31 & CD137, TMEM26, TBX1 \\
\hline
\end{tabular}

properties of BAT [34], when fully utilized may act as an energy sink. There are three ways in which enhanced energy expenditure through manipulation of BAT could be theoretically achieved: i) maximal and continual activation of BAT; ii) trans-differentiation of WAT to BAT (to form BeAT), and; iii) transplantation of BAT stem cells.

The presence of BAT in adult humans represents a potentially important therapeutic target for future novel weight-loss strategies. The origins and functions of BAT, WAT and BeAT differ in important ways, and studies on the energetics of BAT have shown promising results. In the next sections, we discuss the main endocrine determinants of human BAT activity, and how each of these mechanisms could be therapeutically manipulated for promotion of weight-loss.

\section{Review of endocrine determinants of BAT activity Thyroid and BAT}

We have known for over a century that thyroid hormone (TH) increases metabolic rate and thermogenesis in homeothermic species, and hence is an important physiological modulator of energy homeostasis $[35,36] \mathrm{TH}$ stimulates both obligatory and facultative thermogenesis [37] and plays an important role in the regulation of lipid metabolism within adipose tissue $[38,39]$. TH also enhances oxidative phosphorylation through induction of mitochondrial biogenesis and modulation of the expression of genes implicated in the regulation of the mitochondrial respiratory chain [40]. The weight gain and decreased cold tolerance observed in individuals with hypothyroidism, and the weight loss and sweating/heat intolerance observed in patients with hyperthyroidism, are predictable clinical manifestations of alterations in BAT activity [41]. It follows therefore that differences in BAT quantity and/or activity between individuals may also influence the clinical manifestations of hypo- or hyperthyroid states. This may also explain the inter-individual variability of weight changes and heterogeneity of other clinical manifestations of dysthyroid states.

The physiological effects of $\mathrm{TH}$ are exerted at the level of transcription through the thyroid receptors (TR): TR $\alpha$ and TR $\beta$ [42]. TR $\beta$ mediates thyronine (T3) induced $U C P 1$ gene expression, whilst the TR $\alpha$ isoform through T3 regulates facultative thermogenesis in BAT [43]. Type 2 deiodinase (D2) plays an essential role in mediating the full thermogenic response of BAT to adrenergic stimulation via increased thyroxine (T4) to T3 conversion within this tissue [44]. From a therapeutic perspective, it would be desirable to selectively activate TR $\beta$ for UCP1 stimulation to avoid the widespread unwanted effects of TR $\alpha$, the predominant receptor in non-BAT tissues. Thyroid hormone analogues have been explored with variable outcomes. GC-1 compound, a selective TR $\beta$ agonist, induces $U C P 1$ gene expression in rats [43], improves glucose homeostasis [45], increases energy expenditure and reduces fat mass and plasma cholesterol [46]. High-fat feeding and concurrent treatment with the TR $\beta$ selective agonist GC-24 (with a 40-fold higher affinity for $\operatorname{TR} \beta$ than TR $\alpha$ ) resulted in only a partial improvement in metabolic control, probably related to acceleration of resting metabolic rate [47]. Treatment with another TR $\beta$-selective agonist, KB-41 in rats resulted in a $6-8 \%$ weight-loss with significant improvements in glucose homeostasis, cholesterol and triglyceride levels without affecting heart rate, probably due to lack of TR $\alpha$ effects [45].

There are also some promising data from human studies that implicate thyroid hormones having important effects on BAT activity. T3 treatment of differentiated human 


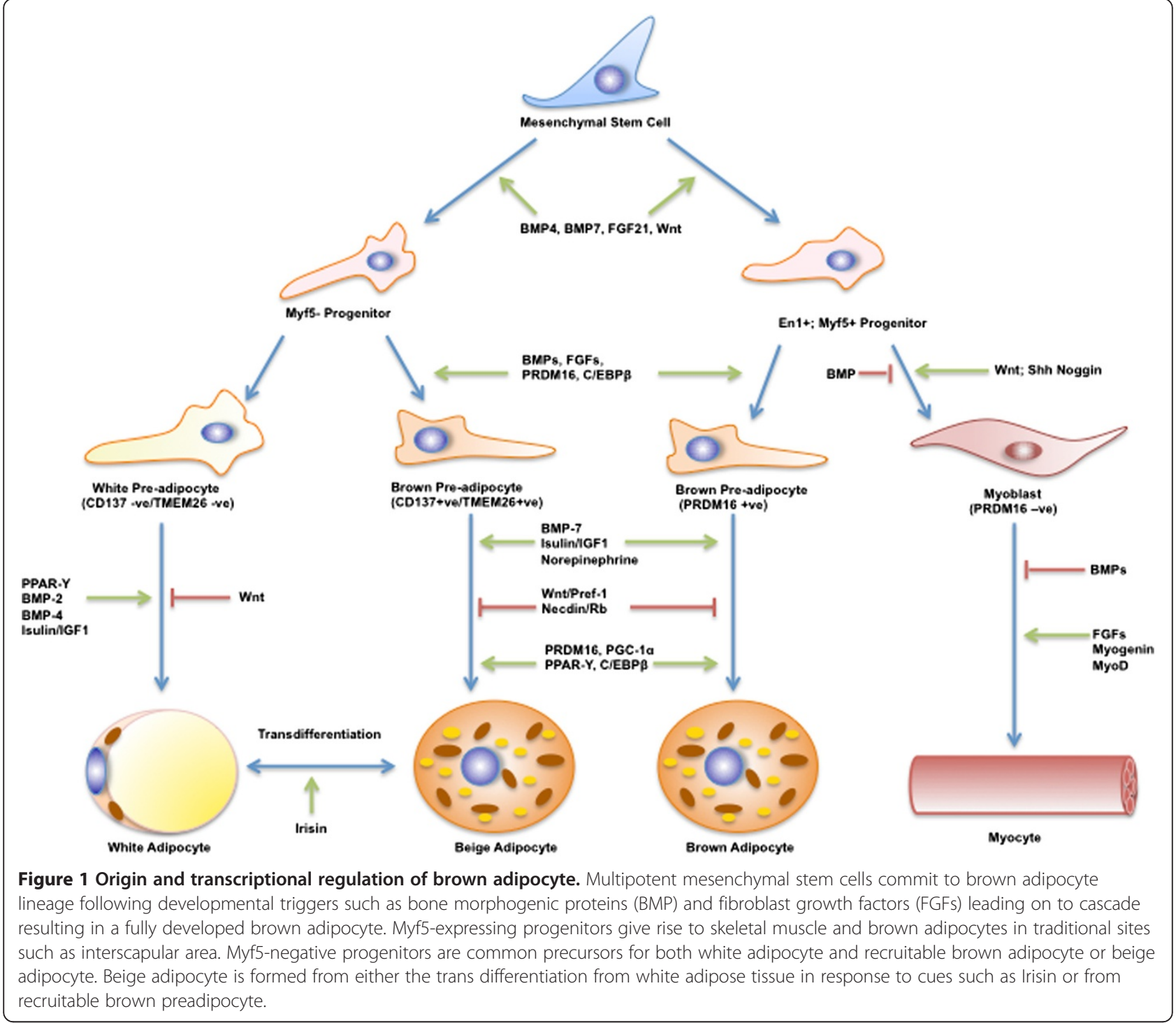

multipotent adipose-derived stem cells in vitro induces UCP1 expression and mitochondrial biogenesis through effects on TR $\beta$ [48]. Following thyroidectomy and subsequent treatment with thyroxine replacement therapy in a patient with papillary carcinoma, BAT activity was enhanced with concurrent weight-loss and remission of T2DM [49]. Thyroxine may cause 'brownification' of WAT [48], and holds immense potential given the mechanism of action in BAT, and hence needs to be robustly tested in humans.

\section{Catecholamines and BAT}

Epinephrine causes vasodilatation and enhances glucose and oxygen consumption in skeletal muscle [50] whilst also enhancing thermogenesis in humans [51]. BAT is also activated in patients with phaeochromocytoma, (excess catecholamine producing benign adrenal medullary tumour) with increased UCP1 expression similar to levels in cold- exposed rodents $[18,52]$. BAT activity is greater in patients with phaeochromocytoma [53,54] due to over-activity of the sympathetic nervous system and elevated levels of circulating catecholamines, that in turn stimulate $\beta 3$ adrenergic receptors, thereby activating $U C P 1$ expression via cyclic adenosine monophosphate (cAMP) and protein kinase-A (PKA) pathways [55]. Hadi et al. demonstrated active BAT to be present in $27 \%(26 / 96)$ of phaeochromocytoma patients undergoing FDG PET-CT scans [56], indicating higher detection rates compared to $5.37 \%(106 / 1972)$ of all cause PET-CT studies reported by Cypess and colleagues [16]. Recent human observational studies demonstrate a correlation between plasma metanephrine levels and BAT activity [57].

Nor-epinephrine action on $\beta 3$-adrenergic receptor in mature human brown adipocyte is the most studied pathways. $\beta 3$-adrenergic receptor would appear to be a convenient 
therapeutic target based on evidence from rodent studies using "selective" $\beta 3$-agonists (CL-316,243) [58] and knockout mouse models [59]. $\beta 3$-agonists have not yielded desirable results in humans due to differences in $\beta 3$-receptor binding properties in humans and rodents. Secondgeneration $\beta 3$-agonist trials in humans were unsuccessful due to poor oral bioavailability and unfavorable pharmacokinetics [60]. Another 33 -agonist, L-796568, showed an initial increase in energy expenditure effect in 12 healthy obese subjects that failed to be sustained beyond 28 days $[61,62]$. Catecholamines may also 'brownify' WAT. Two case reports of extensive brown fat deposits in omental and mesenteric regions detected on human FDG-PET scans indicate a possible role for catecholamines in the 'browning' of WAT [63,64]. Therapeutically, catecholamine-like molecules may trans-differentiate WAT into BeAT, but such an approach would need to avoid the associated sympathomimetic effects to be safe.

\section{Glucocorticoids and BAT}

Both BAT and WAT contain glucocorticoid receptors [65]. Excessive levels of glucocorticoids increase WAT mass and result in weight gain [66]. Conversely, glucocorticoids have an inhibitory effect on BAT activity in rodent models [67]. Glucocorticoids enhance appetite, stimulate lipolysis, suppress thermogenesis [68] (specifically facultative thermogenesis [69]) and profoundly suppress norepinephrine-induced UCP1 activation [67]. Glucocorticoids also inhibit the expression and function of $\beta 1$ and $\beta 3$ adrenergic receptors within BAT. [70,71] Corticosterone reduces NST and increases lipid storage within BAT in an in vivo rodent study, possibly as a result of steroid-induced hyperinsulinaemia [69]. Within rodent models, it has been observed that adrenalectomy results in stimulation of BAT thermogenesis and also weight-loss [72]. This mechanism is probably mediated through removal of glucocorticoid-induced hypothalamic inhibitory influences on BAT activity, and is reversed following glucocorticoid administration [72,73]. A similar reduction in body fat mass was seen in a 46-year old female with Cushing's syndrome following adrenalectomy [74]. The therapeutic challenge here would be to develop the beneficial effects of steroid depletion on metabolism and adipose-regulation whilst avoiding its potentially life-threatening effects.

\section{Mineralocorticoid and BAT}

Mineralocorticoid receptors in rodent BAT, were first demonstrated by Zennaro and colleagues [75]. Following aldosterone treatment of a T37i cell line derived from hibernoma in mice, there was increased expression of adipogenic genes such as $\mathrm{Lpl}$ (lipoprotein lipase), $P P A R-\gamma$ (Peroxisome proliferator receptor activated-gamma) $(P P A R-\gamma)$ and aP2 (adipocyte-specific fatty acid binding protein)
[75,76]. Treatment with aldosterone also results in inhibition of $U_{c p} 1$ expression, favouring lipid storage rather than heat dissipation [77,78]. Within WAT, aldosterone induces inflammation resulting in the release of proinflammatory cytokines such as Interleukin-6 (IL-6), tumour necrosis factor-alpha (TNF- $\alpha$ ) and Monocyte chemo attractant protein (MCP-1) [79]. Aldosterone also appears to inhibit thermogenesis within BAT, and also inhibits the differentiation of WAT into BAT [80]. Given that mineralocorticoids have a negative effect on BAT, it follows that aldosterone antagonists may represent a combined therapy for both hypertension and obesity (through possible activation of BAT). This also supports the findings that high aldosterone levels are noted in obesity-induced hypertension in humans, which reverses on weight loss [81].

\section{Growth hormone/Insulin Growth Factor-1 and BAT}

BAT-status in growth hormone $(\mathrm{GH})$-deficient patients and acromegalics remains unknown. $\mathrm{GH}$ replacement in $\mathrm{GH}-$ deficient humans results in sustained improvement of body composition and reduction of insulin resistance [82,83]. Conversely, GH excess in acromegalics promotes insulin resistance [82], resulting in dysglycaemia and hyperlipidaemia. GH replacement ( $1 \mathrm{mg} / \mathrm{kg} /$ day) for 10 days in experimental mice resulted in significant reduction of WAT mass, increased skeletal weight and reduction of insulin resistance. Despite an increase in $U c p-1$ mRNA by 2.8 fold, there was no change in the inter-scapular brown fat mass [84], although a substantial increase ( 2 to 6 fold) in interscapular brown fat mass was noted at higher doses of $\mathrm{GH}$ (3.5 mg/kg/day).

Insulin Growth Factor-1 (IGF-1) receptors are highly expressed in the plasma membrane of rat brown adipocytes [85]. In vitro studies in murine foetal brown adipocytes have shown that IGF-1 is intensely mitogenic and prevents TNF- $\alpha$ induced apoptosis [86,87]. IGF-1 induces the expression of $U c p-1$ and CCAAT/enhancer binding protein alpha $(\mathrm{C} / \mathrm{EBP}-\alpha)$ in rat brown adipocyte primarycell cultures [88]. Transient up-regulation of Igf-1 gene expression and BAT hyperplasia was noted in rats exposed to cold $\left(4^{\circ} \mathrm{C}\right)$ in the first 48 hours [89]. One of the factors influencing the dramatic rise in human foetal UCP-1 content during late gestation, especially prior to birth, is thought to be due to increased IGF-1 and IGF-2 levels [90]. There may therefore be a role for IGF-1 in BAT differentiation and activation, although the precise molecular mechanisms remain unclear. As a therapeutic strategy, the effect of GH or recombinant human IGF-1 (or truncated IGF-1) on BAT and WAT functioning is worth exploring.

\section{Prolactin and BAT}

Functional prolactin receptors (PRLR) are highly expressed in both WAT and BAT and are essential for adipogenesis 
and adaptive thermogenesis [91]. Prolactin plays important roles in carbohydrate metabolism through its effects on pancreatic $\beta$-cell mass and energy homeostasis through lipid metabolism [92]. Prolactin suppression, through use of dopamine agonists in hyperprolactinaemic patients, results in metabolic effects [93]. Lactation in experimental mice is strongly and negatively associated with expression of thermogenic genes in BAT [94]. PRLR-/- male mice subjected to a high fat diet for 16 weeks exhibited resistance to weight-gain and a reduction in WAT compared to wild-type mice. These mice also showed 2-3 fold increased expression of BAT-specific markers (PR domain containing 16 [PRDM16], UCP1, PPAR-coactivator 1-alpha $[\mathrm{PGC} 1 \alpha])$ and brown-like adipocyte foci, indicating a possible role in BeAT differentiation from WAT [95]. Further studies are required to establish whether prolactin blockade by either dopamine agonists or pure prolactin receptor antagonists may represent a targeted approach for browning of human WAT.

\section{Sex hormones and BAT}

Androgen and oestrogen receptors (ER $\alpha)$ are expressed in BAT in both sexes [96]. Furthermore, sex hormones play an important role in the BAT thermogenic program by acting at several steps of the lipolytic signal cascade and on UCP1 transcription control. Observations such as cessation of ovarian function at menopause resulting in weight-gain, loss of insulin sensitivity and increased incidence of cardiovascular disease [97], coupled with greater BAT activity in young females in PET-CT studies [16], fuel the argument that ovarian hormones probably influence BAT function. Ovariectomy in female rodents reduced BAT mitochondrial functionality through reduction in the oxidative capacity and anti-oxidant defenses. Furthermore, 17- $\beta$ oestradiol (E2) supplementation partially reversed these effects indicating oestrogen's partial influence on BAT [98]. There may also be non-oestrogenic ovarian signals stimulating BAT activity [98]. Interestingly, in vitro cell culture studies by Rodriguez-Cuenca show a dual effect of $17-\beta$ oestradiol on the mitochondrial biogenic program $[99,100]$.

Addition of testosterone reduced norepinephrine-induced Ucp1 mRNA expression in a dose-dependent manner in cultured rodent brown adipocytes, and these effects were reversed by flutamide (an androgen receptor antagonist) [101]. Furthermore, testosterone reduces the thermogenic and lipolytic capacity of BAT [100]. In contrast, progesterone is shown to have the opposite effect to that of testosterone on brown adipocytes [101] by positively stimulating mitochondriogenesis and BAT differentiation as demonstrated by an increase in the mRNA expression of the GABPA-TFAM axis and PPAR- $\gamma$, respectively [99]. These apparent opposite influences of testosterone and progesterone on BAT activity may explain the gender dimorphism displayed by BAT in human PET studies [16,102]. Dehydroepiandrosterone (DHEA, a precursor sex steroid), when administered to obese and lean rats caused reduced food intake and enhanced energy expenditure resulting in weight-loss through increased expression of Pgc-1 $\alpha, U c p 1$ and $\beta 3-A r$ [103].

In summary, these animal studies demonstrate variable effects of sex hormones on BAT activity: testosterone appears to have a negative influence, oestrogen probably has a dual effect and progesterone and DHEA both appear to have positive influences on BAT activity. However, the increase in both, BAT amount and BAT activity in both sexes in human adolescents, (during peak surge of sex hormones) [104] fuels speculation that sex hormones may have a strong influence on BAT. Therefore it is worth exploring the influences of flutamide, selective oestrogen-receptor modulators (SERMs) and DHEA on human BAT activity.

\section{Insulin and BAT}

In cultured murine brown and white adipose tissue, insulin has a role in differentiation of pre-adipocytes into adipocytes [105]. Furthermore, insulin-signaling in BAT is similar to that of WAT and other tissues, displaying similar anabolic effects of glucose uptake and lipid accretion [106]. The studies suggest that uptake of glucose into BAT is both insulin-mediated (mainly occurring in non-thermogenic conditions) and norepinephrine-mediated (occurring during thermogenic conditions) [107]. In rodent models, BAT is shown to be one of the most insulin-responsive tissues with respect to glucose-uptake [108] and is mediated via GLUT4, similar to that in WAT [109].

Animal studies suggest that chronic insulin deficiency reduces the thermogenic capacity of BAT $[110,111]$. Furthermore, in type 1 diabetes mellitus glucose homeostasis is reverted to normalcy by increasing BAT quantity [112]. Contrarily, compensatory hyperinsulinaemia induces apoptosis of endothelial cells in rat BAT, thereby reducing BAT quantity [113]. This may explain reduced BAT activity observed in insulin-resistant states such as human obesity and T2DM in human PET-case series $[16,102]$. In human PET studies, insulin-mediated glucose-uptake by BAT increased 5-fold (independent of perfusion) in comparison to WAT, and gene expression of GLUT4 (Glucose transporter type 4) was higher in BAT than WAT [33]. In summary, it appears that insulin is required in maintenance of BAT thermogenic capacity, but the potential therapeutic role of insulin and insulin-related molecules in BAT manipulation is yet to be determined.

Central or peripheral intravenous leptin administration in rats is shown to increase insulin stimulated glucose utilisation, and to favour expression of uncoupling proteins predominantly through central pathways of increasing sympathetic tone $[114,115]$. However, the lack of success 
of human recombinant leptin infusions on weight loss in obese subjects [116], and adverse cardiovascular profile of hypertension, left ventricular dysfunction, and possible cardiovascular risk [117] may need to be factored in for contemplating leptin route of BAT activation. Adiponectin is noted to inhibit UCP-1 gene expression by suppression of $\beta 3$-adrenergic receptor in rats [118]. Conversely, adiponectin levels were significantly higher in BAT compared to WAT in active phaeochromocytoma patients, and consequently serum adiponectin levels reduced markedly following adrenalectomy [119]. The relation between BAT and adiponectin in humans is yet to be clarified before considering on therapeutic prospects.

\section{Endocannabinoids and BAT}

Acting centrally and peripherally, the endocannabinoid system positively regulates appetite and energy balance [120] and has a role in adipose tissue metabolism [121], mainly through cannabinoid receptors (CB1 and $\mathrm{CB} 2$ ), and their natural endogenous ligands anandamide and 2-arachidonoyl glycerol [120]. In rodents, weight-loss associated with chronic CB1 antagonism was accompanied by increased energy expenditure, enhanced insulin-stimulated glucose utilisation, and marked activation of BAT thermogenesis [122]. Similar mice studies have shown a sustained increase of BAT temperature and up-regulation of UCP1 on CB1 blockade [123]. Through peripheral CB1 receptor inhibition, in vitro murine white adipocytes transdifferentiate into a mitochondria rich, thermogenic BAT phenotype [124]. Experiments with BAT denervation have attenuated such browning responses, indicating that central regulation is essential. Recent withdrawal of rimonabant from the market owing to concerns regarding an adverse psychotropic profile, poses a problem for CB1 being a target for activation of brown fat, unless a more selective peripheral blocker of CB1 is identified. Table 2 enlists effect of various hormones on BAT and possible therapeutic options through manipulation of individual hormonal actions.

\section{Current trends in BAT therapeutics}

Given that adult humans have BAT, it is important to explore BAT manipulation as a means of promoting weightloss through enhanced energy expenditure via BAT manipulation. In addition to augmentation of BAT content and/or enhancement of BAT activity, other approaches include trans-differentiation of non-BAT progenitors into BAT pre-adipocytes, and surgical implantation of BAT. Development of novel BAT-related therapies will require a complete understanding of the embryological and transcriptional mechanisms of BAT specification and development in human models. We also need to characterize and confirm the physical and genetic attributes of BAT including anatomical and histological distributions of human BAT. Further challenges will be to develop a sustained long-term BAT stimulating or recruiting molecular circuit with adequate knowledge of counter-regulatory mechanisms for an acceptable safety profile, and to identify a reliable and safe imaging modality to monitor the effects of such therapies on BAT once developed and administered.

Several transcriptional regulators of brown adipocyte differentiation are described in rodents, with some revealing promising effects even in human models. Irisin is a 112amino-acid polypeptide hormone, and is a cleaved and secreted fragment of fibronectin type III domain containing 5 (FNDC5) membrane protein, in turn released by muscle through increased PGC- $1 \alpha$ expression following exercise in both rodents and humans [125]. Irisin showed a powerful browning effect on certain white adipose tissues in mice, both in culture and in vivo [125]. Human irisin is

\section{Table 2 Effect of hormones on BAT and possible therapeutic options}

\begin{tabular}{|c|c|c|}
\hline Hormone & Influence on BAT & Probable BAT therapeutic suggestions \\
\hline Epinephrine & $+v e$ & Selective human $\beta 3$ receptor agonists \\
\hline $\mathrm{T} 3$ & $+v e$ & TR $\beta$ selective agonists- GC- $40, \mathrm{~KB}-41$ \\
\hline Testosterone & -ve & To be determined \\
\hline Estradiol & $+/-($ ? dual effect $)$ & Selective estrogen receptor modulators (SERM) \\
\hline Progesterone & + ve & To be determined \\
\hline DHEA & +ve & To be determined \\
\hline IGF-1 & Probably + ve & Recombinant human IGF-1 or truncated IGF-1 \\
\hline $\mathrm{GH}$ & +ve at higher dose & To be determined \\
\hline Insulin & Unclear & To be determined \\
\hline Cortisol & -ve & To be determined \\
\hline Prolactin & -ve & Bromocriptine, pure prolactin receptor antagonists eg., $\Delta 1-9-\mathrm{G} 129 \mathrm{R}-\mathrm{hPrl}(\Delta 1-9)$ \\
\hline Aldosterone & -ve & Eplerenone, Spironolactone \\
\hline Endocannabinoids & -ve & Peripheral CB1 antagonists \\
\hline
\end{tabular}


believed to be identical to mouse irisin, and in healthy adult subjects showed a 2 -fold increase in plasma levels following 10 weeks of supervised endurance exercise training, as compared to the non-exercised state [125]. This PGC- $1 \alpha$ dependent myokine alludes to the superadded beneficial effects of exercise via BAT, which need to be further explored.

The PRDM16-C/EBP- $\beta$ transcriptional complex acts in Myogenic Factor-5 (Myf5) positive myoblastic precursors or pre-adipocytes to drive the thermogenic program with co-activation of PPAR- $\gamma$ and PGC- $1 \alpha[126,127]$. The cAMP-dependent thermogenic program is potentiated by Forkhead Box Protein C2 (FOXC2) [128] and PRDM16 and repressed by receptor-interacting protein-140 (RIP140) [129] (Figure 1). Other transcriptional regulators of Bone Morphogenic Protein-7 (BMP7) [130], Fibroblast Derived Growth Factor-21 (FGF21) [131], PPAR- $\gamma$ ligands [132] and Atrial Natriuretic Peptide (ANP) [133], have been described in rodents. The transcripted cells through these various regulators are termed as BeAT as opposed to classical BAT and the success of these compounds depend upon extrapolating the gains in human models.

The discovery of brown adipocyte stem/progenitor cells, CD34+ in skeletal muscle [134] and human multipotent adipose derived stem cells (hMADs) in subcutaneous tissue [135] in adult humans, serve as novel molecular targets for the development of BAT therapeutics as they have self-renewing capacity, and hence are expandable. In response to specific agents, muscle-derived CD34+ cells differentiate exclusively into brown adipocytes [134]. The WAT-derived hMADs, in contrast, first differentiate into WAT and following chronic exposure to PPAR- $\gamma$ co-activators, gain brown adipose phenotype [135]. These human cell models provide a unique opportunity to study the formation and energy dissipation functions of human brown adipocytes, whilst simultaneously exploring therapeutic options. Such cells can potentially be externally induced into BAT, expanded and implanted back as an autologous implantation for metabolic beneficial effects as shown in recent mouse models [136]. Subcutaneous transplantation of embryonic BAT corrected type 1 diabetes in immune-competent mice as evidenced by reversal of diabetes symptoms, weight regain and normalization of glucose tolerance and the mice that remained euglycaemic 6-months following the procedure [137].

\section{Conclusion}

There is compelling evidence to suggest that targeting cellular bioenergetics will yield an effective anti-obesity therapy. There are also complex practical concerns to be addressed. Recent key advances in the fields of molecular cell biology and metabolic science have raised relevant questions relating to the duration of the acquired
BAT-like properties of cells following transcriptional regulation, the long-term fate of transcriptionally converted non-BAT (BeAT) tissues, the total amount of inactive BAT in humans and the fate of inter-scapular BAT in infants. Compensatory enhancement of appetite through central feedback regulation via complex neurological circuits following sustained chronic peripheral energy loss is a concern. Therefore, combining novel therapies that enhance BAT activity with an appetite-suppressant may be required. Therapeutic manipulation of peripheral energy expenditure through increasing BAT quantity and/or activity remains one of the most promising strategies for the successful prevention and management of human obesity. Although there are significant hurdles, there is also great potential for BAT manipulation to promote weight-loss through enhanced facultative metabolism.

\section{Abbreviations}

BAT: Brown adipose tissue; WHO: World Health Organization; T2DM: Type 2 diabetes mellitus; FDG: 18-Fluoro-labelled- 2-deoxyglucose; PET-CT: Positron Emission Tomography- Computed Tomography; WAT: White adipose tissue; BeAT: Beige adipose tissue; UCP-1: Uncoupling protein- 1; ATP: Adenosine tri-phosphate; AEE: Activity energy expenditure; TEE: Total energy expenditure; RMR: Resting metabolic rate; NST: Non-shivering thermogenesis; DIT: Diet-induced thermogenesis; NEFA: Non-esterified fatty acids; TH: Thyroid hormone; TR: Thyroid receptor; D2: type-2-deiodinase; T4: Thyroxine; T3: Thyronine; c-AMP: cyclic adenosine-mono-phosphate; PKA: Protein kinase-A; Lpl: Lipoprotein lipase; PPAR-y: Peroxisome proliferator receptor activated-gamma; aP2: Adipocyte-specific fatty acid binding protein; IL-6: Interleukin-6; TNF-a: Tumour necrosis factor-alpha; MCP-1: Monocyte chemoattractant protein; GH: Growth Hormone; IGF-1: Insulin Growth Factor-1; C/EBP- a: CCAAT-enhancer binding protein- alpha; PRDM-16: PR domain containing 16; PGC-1a: Peroxisome proliferator activated receptor gamma coactivator 1- alpha; CB-1: Cannabinoid receptor-1; ER-a: Oestrogen receptor-alpha; E2: 17- $\beta$-Oestradiol; NRF-1: Nuclear respiratory transcriptional factor-1; GABPA: GA-binding protein transcription protein- alpha; TFAM: Mitochondrial transcription factor-A; PTEN: Phosphatase and tensin homolog deleted on chromosome 10; AR: Adrenergic receptor; SERMs: Selective oestrogen receptor modulators; GLUT-4: Glucose transporter type 4; FNDC-5: Fibronectin type 3 domain containing 5; Myf-5: Myogenic factor-5; FOXC2: Forkhead box protein C2; RIP140: Receptor interacting protein-140; BMP-7: Bone morphogenic protein-7; FGF21: Fibroblast derived growth factor-21; hMADs: Human multi-potent adipocyte derived stem cells.

\section{Competing interests}

The authors declare that they have no competing interests.

\section{Authors' contributions}

NLR researched the data, contributed to discussion, wrote, reviewed and edited the manuscript. BKT and TMB contributed to discussion and edited the manuscript. HSR contributed to conception/design, data interpretation and manuscript preparation. All authors read and approved the final manuscript.

\section{Authors' information}

NLR is a Clinical Lecturer in Division of Metabolic and Vascular Health (DMVH), University of Warwick, and Honorary Consultant in Diabetes \& Endocrinology, University Hospitals Coventry and Warwickshire NHS Trust (UHCW). BKT is an Associate Professor in Warwick Medical School, University of Warwick, and Consultant in Department of Obstetrics and Gynaecology, Birmingham Heartlands Hospital, Heart of England NHS Foundation Trust, Birmingham, UK. TMB is an Associate Professor in DMVH, University of Warwick and Consultant in Diabetes \& Endocrinology, UHCW. HSR is a Senior Lecturer in DMVH, University of Warwick and Clinical Director/Consultant in Diabetes \& Endocrinology, UHCW. 


\section{Acknowledgements}

We would like to acknowledge the many patients, nurses, scientists and doctors who have contributed towards ascertaining the data referred to in this review.

\section{Author details \\ ${ }^{1}$ Clinical Sciences Research Laboratories, Division of Metabolic and Vascular Health, Warwick Medical School, University of Warwick, University Hospitals Coventry and Warwickshire, Clifford Bridge Road, Coventry CV2 2DX, UK. ${ }^{2}$ Warwickshire Institute for Study of Diabetes, Endocrinology and Metabolism, University Hospitals Coventry and Warwickshire NHS Trust, Clifford Bridge Road, Coventry CV2 2DX, UK. ${ }^{3}$ Obstetrics and Gynaecology, Birmingham Heartlands and Solihull Hospitals, Heart of England NHS Foundation Trust, Birmingham B9 5SS, UK.}

Received: 27 January 2014 Accepted: 18 July 2014

Published: 22 August 2014

\section{References}

1. WHO global infobase: data on overweight and obesity. http://www.who int/mediacentre/factsheets/fs311/en/.

2. Larsson B, Svardsudd K, Welin L, Wilhelmsen L, Bjorntorp P, Tibblin G: Abdominal adipose tissue distribution, obesity, and risk of cardiovascular disease and death: 13 year follow up of participants in the study of men born in 1913. Br Med J (Clin Res Ed) 1984, 288:1401-1404.

3. Lim SS, Vos T, Flaxman AD, Danaei G, Shibuya K, Adair-Rohani H, Amann M, Anderson HR, Andrews KG, Aryee M, Lim SS, Vos T, Flaxman AD, Danaei G, Shibuya K, Adair-Rohani H, Amann M, Anderson HR, Andrews KG, Aryee M, Atkinson C, Bacchus L, Bahalim AN, Balakrishnan K, Balmes J, Barker-Collo S, Baxter A, Bell ML, Blore JD, Blyth F, et al: A comparative risk assessment of burden of disease and injury attributable to 67 risk factors and risk factor clusters in 21 regions, 1990-2010: a systematic analysis for the Global Burden of Disease Study 2010. Lancet 2012, 380:2224-2260.

4. Ng M, Fleming T, Robinson M, Thomson B, Graetz N, Margono C, Mullany EC, Biryukov S, Abbafati C, Abera SF, Abraham JP, Abu-Rmeileh NM, Achoki T, AlBuhairan FS, Alemu ZA, Alfonso R, Ali MK, Ali R, Guzman NA, Ammar W, Anwari P, Banerjee A, Barquera S, Basu S, Bennett DA, Bhutta Z, Blore J, Cabral N, Nonato IC, Chang JC: Global, regional, and national prevalence of overweight and obesity in children and adults during 1980-2013: a systematic analysis for the Global Burden of Disease Study 2013. Lancet 2014, e-publication ahead of print.

5. Scott A, Ejikeme CS, Clottey EN, Thomas JG: Obesity in sub-Saharan Africa: development of an ecological theoretical framework. Health Promot Int 2013, 28:4-16.

6. Sumithran P, Prendergast LA, Delbridge E, Purcell K, Shulkes A, Kriketos A, Proietto J: Long-term persistence of hormonal adaptations to weight loss. N Engl J Med 2011, 365:1597-1604

7. Rosenbaum M, Hirsch J, Gallagher DA, Leibel RL: Long-term persistence of adaptive thermogenesis in subjects who have maintained a reduced body weight. Am J Clin Nutr 2008, 88:906-912

8. Padwal R, Li SK, Lau DC: Long-term pharmacotherapy for obesity and overweight. Cochrane Database Syst Rev 2004, 3:CD004094.

9. Dixon JB, Zimmet P, Alberti KG, Rubino F: Bariatric surgery: an IDF statement for obese Type 2 diabetes. Surg Obes Relat Dis 2011, 7:433-447.

10. Padwal RS, Majumdar SR: Drug treatments for obesity: orlistat, sibutramine, and rimonabant. Lancet 2007, 369:71-77.

11. Tseng YH, Cypess AM, Kahn CR: Cellular bioenergetics as a target for obesity therapy. Nat Rev Drug Discov 2010, 9:465-482.

12. Wells JC: Thrift: a guide to thrifty genes, thrifty phenotypes and thrifty norms. Int J Obes (Lond) 2009, 33:1331-1338.

13. Fawcett DW, Jones IC: The effects of hypophysectomy, adrenalectomy and of thiouracil feeding on the cytology of brown adipose tissue. Endocrinology 1949, 45:609-621. illust.

14. Virtanen KA, Lidell ME, Orava J, Heglind M, Westergren R, Niemi T, Taittonen M, Laine J, Savisto NJ, Enerback S, Nuutila P: Functional brown adipose tissue in healthy adults. N Engl J Med 2009, 360:1518-1525.

15. Hany TF, Gharehpapagh E, Kamel EM, Buck A, Himms-Hagen J, von Schulthess GK: Brown adipose tissue: a factor to consider in symmetrical tracer uptake in the neck and upper chest region. Eur J Nucl Med Mol Imaging 2002, 29:1393-1398.
16. Cypess AM, Lehman S, Williams G, Tal I, Rodman D, Goldfine AB, Kuo FC, Palmer EL, Tseng YH, Doria A, Kolodny GM, Kahn CR: Identification and importance of brown adipose tissue in adult humans. N Eng/ J Med 2009, 360:1509-1517.

17. Guerra C, Koza RA, Yamashita H, Walsh K, Kozak LP: Emergence of brown adipocytes in white fat in mice is under genetic control: effects on body weight and adiposity. J Clin Invest 1998, 102:412-420.

18. Lean ME, James WP, Jennings G, Trayhurn P: Brown adipose tissue in patients with phaeochromocytoma. Int J Obes (Lond) 1986, 10:219-227.

19. Lahesmaa M, Orava J, Schalin-Jantti C, Soinio M, Hannukainen JC, Noponen T, Kirjavainen A, lida H, Kudomi N, Enerback S, Virtanen KA, Nuutila P: Hyperthyroidism increases brown fat metabolism in humans. J Clin Endocrinol Metab 2014, 99:E28-E35.

20. Enerback S: Brown adipose tissue in humans. Int J Obes (Lond) 2010, 34(Suppl 1):S43-S46.

21. Wu J, Bostrom P, Sparks LM, Ye L, Choi JH, Giang AH, Khandekar M, Virtanen KA, Nuutila P, Schaart G, Huang K, Tu H, Van Marken Lichtenbelt WD, Hoeks J, Enerbäck S, Schrauwen P, Spiegelman BM: Beige adipocytes are a distinct type of thermogenic fat cell in mouse and human. Cell 2012, 150:366-376.

22. Whittle AJ, Lopez M, Vidal-Puig A: Using brown adipose tissue to treat obesity - the central issue. Trends Mol Med 2011, 17:405-411.

23. van Marken Lichtenbelt WD, Schrauwen P: Implications of nonshivering thermogenesis for energy balance regulation in humans. Am J Physiol Regul Integr Comp Physiol 2011, 301:R285-R296.

24. Westerterp KR, Wilson SA, Rolland V: Diet induced thermogenesis measured over $24 \mathrm{~h}$ in a respiration chamber: effect of diet composition. Int J Obes Relat Metab Disord 1999, 23:287-292.

25. Saito M, Okamatsu-Ogura Y, Matsushita M, Watanabe K, Yoneshiro T, Nio-Kobayashi J, Iwanaga T, Miyagawa M, Kameya T, Nakada K, Kawai Y, Tsujisaki M: High incidence of metabolically active brown adipose tissue in healthy adult humans: effects of cold exposure and adiposity. Diabetes 2009, 58:1526-1531.

26. van Marken Lichtenbelt WD, Vanhommerig JW, Smulders NM, Drossaerts JM, Kemerink GJ, Bouvy ND, Schrauwen P, Teule GJ: Cold-activated brown adipose tissue in healthy men. $N$ Engl J Med 2009, 360:1500-1508.

27. Nicholls DG, Locke RM: Thermogenic mechanisms in brown fat. Physiol Rev 1984, 64:1-64.

28. Kozak LP: Brown fat and the myth of diet-induced thermogenesis. Cell Metab 2010, 11:263-267.

29. Ouellet V, Labbe SM, Blondin DP, Phoenix S, Guerin B, Haman F, Turcotte EE, Richard D, Carpentier AC: Brown adipose tissue oxidative metabolism contributes to energy expenditure during acute cold exposure in humans. J Clin Invest 2012, 122:545-552.

30. Rothwell NJ, Stock MJ: Luxuskonsumption, diet-induced thermogenesis and brown fat: the case in favour. Clin Sci (Lond) 1983, 64:19-23.

31. Yoneshiro T, Aita S, Matsushita M, Kameya T, Nakada K, Kawai Y, Saito M: Brown adipose tissue, whole-body energy expenditure, and thermogenesis in healthy adult men. Obesity (Silver Spring) 2011, 19:13-16.

32. Muzik $\mathrm{O}$, Mangner TJ, Granneman JG: Assessment of oxidative metabolism in brown fat using PET imaging. Front Endocrinol (Lausanne) 2012, 3:15.

33. Orava J, Nuutila P, Lidell ME, Oikonen V, Noponen T, Viljanen T, Scheinin M, Taittonen M, Niemi T, Enerback S, Virtanen KA: Different metabolic responses of human brown adipose tissue to activation by cold and insulin. Cell Metab 2011, 14:272-279.

34. Bartelt A, Bruns OT, Reimer R, Hohenberg H, Ittrich H, Peldschus K, Kaul MG, Tromsdorf UI, Weller H, Waurisch C, Eychmüller A, Gordts PL, Rinninger F, Bruegelmann K, Freund B, Nielsen P, Merkel M, Heeren J: Brown adipose tissue activity controls triglyceride clearance. Nat Med 2011, 17:200-205.

35. Klitgaard HM, Dirks HB Jr, Garlick WR, Barker SB: Protein-bound iodine in various tissues after injection of elemental iodine. Endocrinology 1952, 50:170-173

36. Klieverik LP, Coomans CP, Endert E, Sauerwein HP, Havekes LM, Voshol PJ, Rensen PC, Romijn JA, Kalsbeek A, Fliers E: Thyroid hormone effects on whole-body energy homeostasis and tissue-specific fatty acid uptake in vivo. Endocrinology 2009, 150:5639-5648.

37. Silva JE: Thermogenic mechanisms and their hormonal regulation. Physiol Rev 2006, 86:435-464.

38. Jiang W, Miyamoto T, Kakizawa T, Sakuma T, Nishio S, Takeda T, Suzuki S, Hashizume K: Expression of thyroid hormone receptor alpha in $3 \mathrm{~T} 3-\mathrm{L} 1$ 
adipocytes; triiodothyronine increases the expression of lipogenic enzyme and triglyceride accumulation. J Endocrinol 2004, 182:295-302.

39. Viguerie N, Millet L, Avizou S, Vidal H, Larrouy D, Langin D: Regulation of human adipocyte gene expression by thyroid hormone. J Clin Endocrinol Metab 2002, 87:630-634.

40. Sheehan TE, Kumar PA, Hood DA: Tissue-specific regulation of cytochrome c oxidase subunit expression by thyroid hormone. Am J Physiol Endocrinol Metab 2004, 286:E968-E974.

41. Lopez M, Varela L, Vazquez MJ, Rodriguez-Cuenca S, Gonzalez CR, Velagapudi VR, Morgan DA, Schoenmakers E, Agassandian K, Lage R, Martínez de Morentin PB, Tovar S, Nogueiras R, Carling D, Lelliott C, Gallego R, Oresic M, Chatterjee K, Saha AK, Rahmouni K, Diéguez C, Vidal-Puig A: Hypothalamic AMPK and fatty acid metabolism mediate thyroid regulation of energy balance. Nat Med 2010, 16:1001-1008.

42. Brent GA: The molecular basis of thyroid hormone action. N Engl J Med 1994, 331:847-853.

43. Ribeiro MO, Carvalho SD, Schultz JJ, Chiellini G, Scanlan TS, Bianco AC, Brent GA: Thyroid hormone-sympathetic interaction and adaptive thermogenesis are thyroid hormone receptor isoform-specific. J Clin Invest 2001, 108:97-105.

44. Bianco AC, Silva JE: Cold exposure rapidly induces virtual saturation of brown adipose tissue nuclear T3 receptors. Am J Physiol 1988, 255:E496-E503.

45. Bryzgalova G, Effendic S, Khan A, Rehnmark S, Barbounis P, Boulet J, Dong G, Singh R, Shapses S, Malm J, Webb P, Baxter JD, Grover GJ: Anti-obesity, anti-diabetic, and lipid lowering effects of the thyroid receptor beta subtype selective agonist KB-141. J Steroid Biochem Mol Biol 2008, 111:262-267.

46. Grover GJ, Egan DM, Sleph PG, Beehler BC, Chiellini G, Nguyen NH, Baxter JD, Scanlan TS: Effects of the thyroid hormone receptor agonist GC-1 on metabolic rate and cholesterol in rats and primates: selective actions relative to 3,5,3'-triiodo-L-thyronine. Endocrinology 2004, 145:1656-1661.

47. Amorim BS, Ueta CB, Freitas BC, Nassif RJ, Gouveia CH, Christoffolete MA, Moriscot AS, Lancelloti CL, Llimona F, Barbeiro HV, de Souza HP, Catanozi S, Passarelli M, Aoki MS, Bianco AC, Ribeiro MO: A TRbeta-selective agonist confers resistance to diet-induced obesity. J Endocrinol 2009, 203:291-299.

48. Lee JY, Takahashi N, Yasubuchi M, Kim Yl, Hashizaki H, Kim MJ, Sakamoto T, Goto T, Kawada T: Triiodothyronine induces UCP1 expression and mitochondrial biogenesis in human adipocytes. Am J Physiol Cell Physiol 2011, 302:463-472

49. Skarulis MC, Celi FS, Mueller E, Zemskova M, Malek R, Hugendubler L, Cochran C, Solomon J, Chen C, Gorden P: Thyroid hormone induced brown adipose tissue and amelioration of diabetes in a patient with extreme insulin resistance. J Clin Endocrinol Metab 2010, 95:256-262.

50. Simonsen L, Bulow J, Madsen J, Christensen NJ: Thermogenic response to epinephrine in the forearm and abdominal subcutaneous adipose tissue. Am J Physiol 1992, 263:E850-E855.

51. Simonsen L, Stallknecht B, Bulow J: Contribution of skeletal muscle and adipose tissue to adrenaline-induced thermogenesis in man. Int J Obes Relat Metab Disord 1993, 17(3):S47-S51. discussion S68.

52. Ricquier D, Nechad M, Mory G: Ultrastructural and biochemical characterization of human brown adipose tissue in pheochromocytoma. J Clin Endocrinol Metab 1982, 54:803-807.

53. English JT, Patel SK, Flanagan MJ: Association of pheochromocytomas with brown fat tumors. Radiology 1973, 107:279-281.

54. Melicow MM: Hibernating fat and pheochromocytoma. AMA Arch Pathol 1957, 63:367-372.

55. Bouillaud F, Ricquier D, Mory G, Thibault J: Increased level of mRNA for the uncoupling protein in brown adipose tissue of rats during thermogenesis induced by cold exposure or norepinephrine infusion. J Biol Chem 1984, 259:11583-11586.

56. Hadi M, Chen CC, Whatley M, Pacak K, Carrasquillo JA: Brown fat imaging with (18)F-6-fluorodopamine PET/CT, (18)F-FDG PET/CT, and (123)I-MIBG SPECT: a study of patients being evaluated for pheochromocytoma. J Nucl Med 2007, 48:1077-1083.

57. Wang $Q$, Zhang $M$, Ning G, Gu W, Su T, Xu M, Li B, Wang W: Brown adipose tissue in humans is activated by elevated plasma catecholamines levels and is inversely related to central obesity. PLoS One 2011, 6:e21006.

58. Himms-Hagen J, Cui J, Danforth E Jr, Taatjes DJ, Lang SS, Waters BL, Claus $\mathrm{TH}$ : Effect of CL-316,243, a thermogenic beta 3-agonist, on energy balance and brown and white adipose tissues in rats. Am J Physiol 1994, 266:R1371-R1382

59. Susulic VS, Frederich RC, Lawitts J, Tozzo E, Kahn BB, Harper ME, HimmsHagen J, Flier JS, Lowell BB: Targeted disruption of the beta 3-adrenergic receptor gene. J Biol Chem 1995, 270:29483-29492.

60. Arch JR: The discovery of drugs for obesity, the metabolic effects of leptin and variable receptor pharmacology: perspectives from beta3adrenoceptor agonists. Naunyn Schmiedebergs Arch Pharmacol 2008, 378:225-240.

61. Larsen TM, Toubro S, van Baak MA, Gottesdiener KM, Larson P, Saris WH, Astrup A: Effect of a 28-d treatment with L-796568, a novel beta(3)adrenergic receptor agonist, on energy expenditure and body composition in obese men. Am J Clin Nutr 2002, 76:780-788.

62. van Baak MA, Hul GB, Toubro S, Astrup A, Gottesdiener KM, DeSmet M, Saris WH: Acute effect of L-796568, a novel beta 3-adrenergic receptor agonist, on energy expenditure in obese men. Clin Pharmacol Ther 2002, 71:272-279.

63. Joshi PV, Lele VR: Unexpected visitor on FDG PET/CT-brown adipose tissue (BAT) in mesentery in a case of retroperitoneal extra-adrenal pheochromocytoma: is the BAT activation secondary to catecholaminesecreting pheochromocytoma? Clin Nucl Med 2012, 37:e119-e120.

64. Cheng W, Zhu Z, Jin X, Chen L, Zhuang H, Li F: Intense FDG activity in the brown adipose tissue in omental and mesenteric regions in a patient with malignant pheochromocytoma. Clin Nucl Med 2012, 37:514-515.

65. Feldman D: Evidence that brown adipose tissue is a glucocorticoid target organ. Endocrinology 1978, 103:2091-2097.

66. Strack AM, Sebastian RJ, Schwartz MW, Dallman MF: Glucocorticoids and insulin: reciprocal signals for energy balance. Am J Physiol 1995, 268:R142-R149.

67. Soumano K, Desbiens S, Rabelo R, Bakopanos E, Camirand A, Silva JE: Glucocorticoids inhibit the transcriptional response of the uncoupling protein-1 gene to adrenergic stimulation in a brown adipose cell line. Mol Cell Endocrinol 2000, 165:7-15.

68. Garrel DR: Glucocorticoids and energy expenditure: relevance to the regulation of energy balance in man. Nutrition 1997, 13:482-483.

69. Strack AM, Bradbury MJ, Dallman MF: Corticosterone decreases nonshivering thermogenesis and increases lipid storage in brown adipose tissue. Am J Physiol 1995, 268:R183-R191.

70. Feve B, Baude B, Krief S, Strosberg AD, Pairault J, Emorine LJ: Inhibition by dexamethasone of beta 3 -adrenergic receptor responsiveness in 3 T3-F442A adipocytes. Evidence for a transcriptional mechanism. J Biol Chem 1992, 267:15909-15915.

71. Kiely J, Hadcock JR, Bahouth SW, Malbon CC: Glucocorticoids down-regulate beta 1-adrenergic-receptor expression by suppressing transcription of the receptor gene. Biochem J 1994, 302(Pt 2):397-403.

72. Vander Tuig JG, Ohshima K, Yoshida T, Romsos DR, Bray GA: Adrenalectomy increases norepinephrine turnover in brown adipose tissue of obese (ob/ob) mice. Life Sci 1984, 34:1423-1432.

73. Berthiaume M, Sell H, Lalonde J, Gelinas Y, Tchernof A, Richard D, Deshaies Y: Am J Physiol Regul Integr Comp Physiol. Am J Physiol Regul Integr Comp Physiol 2004, 287:R1116-R1123.

74. Ashizawa N, Takagi M, Seto S, Suzuki S, Yano K: Serum adiponectin and leptin in a patient with Cushing's syndrome before and after adrenalectomy. Intern Med 2007, 46:383-385.

75. Zennaro MC, Le Menuet D, Viengchareun S, Walker F, Ricquier D, Lombes $\mathrm{M}$ : Hibernoma development in transgenic mice identifies brown adipose tissue as a novel target of aldosterone action. J Clin Invest 1998, 101:1254-1260.

76. Penfornis P, Viengchareun S, Le Menuet D, Cluzeaud F, Zennaro MC, Lombes M: The mineralocorticoid receptor mediates aldosteroneinduced differentiation of T37i cells into brown adipocytes. Am J Physiol Endocrinol Metab 2000, 279:E386-E394.

77. Viengchareun S, Penfornis P, Zennaro MC, Lombes M: Mineralocorticoid and glucocorticoid receptors inhibit UCP expression and function in brown adipocytes. Am J Physiol Endocrinol Metab 2001, 280:E640-E649.

78. Kraus D, Jager J, Meier B, Fasshauer M, Klein J: Aldosterone inhibits uncoupling protein-1, induces insulin resistance, and stimulates proinflammatory adipokines in adipocytes. Horm Metab Res 2005, 37:455-459.

79. Hoppmann J, Perwitz N, Meier B, Fasshauer M, Hadaschik D, Lehnert H, Klein $\mathrm{J}$ : The balance between gluco- and mineralo-corticoid action critically 
determines inflammatory adipocyte responses. J Endocrinol 2010, 204:153-164.

80. Marzolla V, Armani A, Zennaro MC, Cinti F, Mammi C, Fabbri A, Rosano GM, Caprio M: The role of the mineralocorticoid receptor in adipocyte biology and fat metabolism. Mol Cell Endocrinol 2012, 350:281-288

81. Feraco A, Armani A, Mammi C, Fabbri A, Rosano GM, Caprio M: Role of mineralocorticoid receptor and renin-angiotensin-aldosterone system in adipocyte dysfunction and obesity. J Steroid Biochem Mol Biol 2013, 137:99-106.

82. Al-Shoumer KA, Page B, Thomas E, Murphy M, Beshyah SA, Johnston DG: Effects of four years' treatment with biosynthetic human growth hormone (GH) on body composition in GH-deficient hypopituitary adults. Eur J Endocrinol 1996, 135:559-567.

83. Hoffman AR, Kuntze JE, Baptista J, Baum HB, Baumann GP, Biller BM, Clark RV, Cook D, Inzucchi SE, Kleinberg D, Klibanski A, Phillips LS, Ridgway EC Robbins RJ, Schlechte J, Sharma M, Thorner MO, Vance ML: Growth hormone $(\mathrm{GH})$ replacement therapy in adult-onset gh deficiency: effects on body composition in men and women in a double-blind, randomized, placebo-controlled trial. J Clin Endocrinol Metab 2004, 89:2048-2056

84. Hioki C, Yoshida T, Kogure A, Takakura Y, Umekawa T, Yoshioka K, Shimatsu A, Yoshikawa T: Effects of growth hormone $(G H)$ on mRNA levels of uncoupling proteins 1, 2, and 3 in brown and white adipose tissues and skeletal muscle in obese mice. Horm Metab Res 2004, 36:607-613.

85. Lorenzo M, Valverde AM, Teruel T, Benito M: IGF-I is a mitogen involved in differentiation-related gene expression in fetal rat brown adipocytes. J Cell Biol 1993, 123:1567-1575.

86. Valverde AM, Benito M, Lorenzo M: Proliferation of fetal brown adipocyte primary cultures: relationship with the genetic expression of glucose 6 phosphate dehydrogenase. Exp Cell Res 1991, 194:232-237.

87. Porras A, Alvarez AM, Valladares A, Benito M: TNF-alpha induces apoptosis in rat fetal brown adipocytes in primary culture. FEBS Lett 1997, 416:324-328.

88. Guerra C, Benito M, Fernandez M: IGF-I induces the uncoupling protein gene expression in fetal rat brown adipocyte primary cultures: role of C/EBP transcription factors. Biochem Biophys Res Commun 1994, 201:813-819.

89. Duchamp C, Burton KA, Geloen A, Dauncey MJ: Transient upregulation of IGF-I gene expression in brown adipose tissue of cold-exposed rats. Am J Physiol 1997, 272:E453-E460.

90. Symonds ME, Mostyn A, Pearce S, Budge H, Stephenson T: Endocrine and nutritional regulation of fetal adipose tissue development. J Endocrinol 2003, 179:293-299.

91. Viengchareun S, Servel N, Feve B, Freemark M, Lombes M, Binart N: Prolactin receptor signaling is essential for perinatal brown adipocyte function: a role for insulin-like growth factor-2. PLoS One 2008, 3:e1535.

92. Ben-Jonathan N, LaPensee CR, LaPensee EW: What can we learn from rodents about prolactin in humans? Endocr Rev 2008, 29:1-41.

93. Pijl H, Ohashi S, Matsuda M, Miyazaki Y, Mahankali A, Kumar V, Pipek R, lozzo P, Lancaster JL, Cincotta AH, DeFronzo RA: Bromocriptine: a novel approach to the treatment of type 2 diabetes. Diabetes Care 2000, 23:1154-1161.

94. Krol E, Martin SA, Huhtaniemi IT, Douglas A, Speakman JR: Negative correlation between milk production and brown adipose tissue gene expression in lactating mice. J Exp Bio/ 2011, 214:4160-4170.

95. Julien Auffret SV, Adeline M, Bruno F, Marc L, Nadine B: Mice lacking prolactin receptor resist high-fat diet-induced obesity by browning of adipose tissue. Endocr Rev 2011, 32:p1-p787.

96. Rodriguez-Cuenca S, Monjo M, Frontera M, Gianotti M, Proenza AM, Roca P Sex steroid receptor expression profile in brown adipose tissue: effects of hormonal status. Cell Physiol Biochem 2007, 20:877-886

97. Gaspard U: Hyperinsulinaemia, a key factor of the metabolic syndrome in postmenopausal women. Maturitas 2009, 62:362-365.

98. Nadal-Casellas A, Proenza AM, Llado I, Gianotti M: Effects of ovariectomy and 17-beta estradiol replacement on rat brown adipose tissue mitochondrial function. Steroids 2011, 76:1051-1056.

99. Rodriguez-Cuenca S, Monjo M, Gianotti M, Proenza AM, Roca P: Expression of mitochondrial biogenesis-signaling factors in brown adipocytes is influenced specifically by 17 beta-estradiol, testosterone, and progesterone. Am J Physiol Endocrinol Metab 2007, 292:E340-E346.

100. Monjo M, Rodriguez AM, Palou A, Roca P: Direct effects of testosterone, 17 beta-estradiol, and progesterone on adrenergic regulation in cultured brown adipocytes: potential mechanism for gender-dependent thermogenesis. Endocrinology 2003, 144:4923-4930.

101. Rodriguez AM, Monjo M, Roca P, Palou A: Opposite actions of testosterone and progesterone on UCP1 mRNA expression in cultured brown adipocytes. Cell Mol Life Sci 2002, 59:1714-1723.

102. Ouellet V, Routhier-Labadie A, Bellemare W, Lakhal-Chaieb L, Turcotte E, Carpentier AC, Richard D: Outdoor temperature, age, sex, body mass index, and diabetic status determine the prevalence, mass, and glucose-uptake activity of 18 F-FDG-detected BAT in humans. J Clin Endocrinol Metab 2011, 96:192-199.

103. Ryu JW, Kim MS, Kim CH, Song KH, Park JY, Lee JD, Kim JB, Lee KU: DHEA administration increases brown fat uncoupling protein 1 levels in obese OLETF rats. Biochem Biophys Res Commun 2003, 303:726-731.

104. Gilsanz V, Hu HH, Kajimura S: Relevance of brown adipose tissue in infancy and adolescence. Pediatr Res 2013, 73:3-9.

105. Tseng YH, Kriauciunas KM, Kokkotou E, Kahn CR: Differential roles of insulin receptor substrates in brown adipocyte differentiation. Mol Cell Biol 2004, 24:1918-1929.

106. Tanti JF, Gremeaux T, Brandenburg D, Van Obberghen E, Le Marchand-Bruste $Y$ : Brown adipose tissue in lean and obese mice. Insulin-receptor binding and tyrosine kinase activity. Diabetes 1986, 35:1243-1248.

107. Shimizu Y, Kielar D, Minokoshi Y, Shimazu T: Noradrenaline increases glucose transport into brown adipocytes in culture by a mechanism different from that of insulin. Biochem J 1996, 314(Pt 2):485-490.

108. Storlien LH, James DE, Burleigh KM, Chisholm DJ, Kraegen EW: Fat feeding causes widespread in vivo insulin resistance, decreased energy expenditure, and obesity in rats. Am J Physio/ 1986, 251:E576-E583.

109. Shimizu Y, Nikami H, Tsukazaki K, Machado UF, Yano H, Seino Y, Saito M: Increased expression of glucose transporter GLUT-4 in brown adipose tissue of fasted rats after cold exposure. Am J Physiol 1993, 264:E890-E895.

110. Rothwell NJ, Stock MJ: A role for insulin in the diet-induced thermogenesis of cafeteria-fed rats. Metabolism 1981, 30:673-678.

111. Shibata $H$, Perusse $F$, Bukowiecki $L J$ : The role of insulin in nonshivering thermogenesis. Can J Physiol Pharmacol 1987, 65:152-158.

112. Gunawardana SC, Piston DW: Reversal of type 1 diabetes in mice by brown adipose tissue transplant. Diabetes 2012, 61:674-682

113. Markelic M, Velickovic K, Golic I, Otasevic V, Stancic A, Jankovic A, Vucetic M, Buzadzic B, Korac B, Korac A: Endothelial cell apoptosis in brown adipose tissue of rats induced by hyperinsulinaemia: the possible role of TNF-alpha. Eur J Histochem 2011, 55:e34.

114. Rouru J, Cusin I, Zakrzewska KE, Jeanrenaud B, Rohner-Jeanrenaud F: Effects of intravenously infused leptin on insulin sensitivity and on the expression of uncoupling proteins in brown adipose tissue. Endocrinology 1999, 140:3688-3692.

115. Enriori PJ, Sinnayah P, Simonds SE, Garcia Rudaz C, Cowley MA: Leptin action in the dorsomedial hypothalamus increases sympathetic tone to brown adipose tissue in spite of systemic leptin resistance. J Neurosci 2011, 31:12189-12197.

116. Heymsfield SB, Greenberg AS, Fujioka K, Dixon RM, Kushner R, Hunt T, Lubina JA, Patane J, Self B, Hunt P, McCamish M: Recombinant leptin for weight loss in obese and lean adults: a randomized, controlled, dose-escalation trial. Jama 1999, 282:1568-1575.

117. Koh KK, Park SM, Quon MJ: Leptin and cardiovascular disease: response to therapeutic interventions. Circulation 2008, 117:3238-3249.

118. Qiao L, Yoo H, Bosco C, Lee B, Feng GS, Schaack J, Chi NW, Shao J: Adiponectin reduces thermogenesis by inhibiting brown adipose tissue activation in mice. Diabetologia 2014, 57:1027-1036.

119. lacobellis G, Di Gioia C, Petramala L, Chiappetta C, Serra V, Zinnamosca L, Marinelli C, Ciardi A, De Toma G, Letizia C: Brown fat expresses adiponectin in humans. Int J Endocrinol 2013, 2013:126751.

120. Rinaldi-Carmona M, Barth F, Heaulme M, Shire D, Calandra B, Congy C, Martinez S, Maruani J, Neliat G, Caput D, Ferrara P, Soubrié P, Brelière JC, Le Fur G: SR141716A, a potent and selective antagonist of the brain cannabinoid receptor. FEBS Lett 1994, 350:240-244.

121. Muccioli GG, Naslain D, Backhed F, Reigstad CS, Lambert DM, Delzenne NM, Cani PD: The endocannabinoid system links gut microbiota to adipogenesis. Mol Syst Biol 2010, 6:392.

122. Bajzer M, Olivieri M, Haas MK, Pfluger PT, Magrisso IJ, Foster MT, Tschop MH, Krawczewski-Carhuatanta KA, Cota D, Obici S: Cannabinoid receptor 1 
(CB1) antagonism enhances glucose utilisation and activates brown adipose tissue in diet-induced obese mice. Diabetologia 2011, 54:3121-3131.

123. Verty AN, Allen AM, Oldfield BJ: The effects of rimonabant on brown adipose tissue in rat: implications for energy expenditure. Obesity (Silver Spring) 2009, 17:254-261.

124. Perwitz N, Wenzel J, Wagner I, Buning J, Drenckhan M, Zarse K, Ristow M, Lilienthal W, Lehnert $\mathrm{H}$, Klein J: Cannabinoid type 1 receptor blockade induces transdifferentiation towards a brown fat phenotype in white adipocytes. Diabetes Obes Metab 2010, 12:158-166.

125. Bostrom P, Wu J, Jedrychowski MP, Korde A, Ye L, Lo JC, Rasbach KA, Bostrom EA, Choi JH, Long JZ, Kajimura S, Zingaretti MC, Vind BF, Tu H, Cinti S, Højlund K, Gygi SP, Spiegelman BM: A PGC1-alpha-dependent myokine that drives brown-fat-like development of white fat and thermogenesis. Nature 2012, 481:463-468.

126. Seale P, Bjork B, Yang W, Kajimura S, Chin S, Kuang S, Scime A, Devarakonda S, Conroe HM, Erdjument-Bromage H, Tempst P, Rudnicki MA, Beier DR, Spiegelman BM: PRDM16 controls a brown fat/skeletal muscle switch. Nature 2008, 454:961-967.

127. Kajimura S, Seale P, Kubota K, Lunsford E, Frangioni JV, Gygi SP, Spiegelman BM: Initiation of myoblast to brown fat switch by a PRDM16-C/EBP-beta transcriptional complex. Nature 2009, 460:1154-1158.

128. Cederberg A, Gronning LM, Ahren B, Tasken K, Carlsson P, Enerback S: FOXC2 is a winged helix gene that counteracts obesity, hypertriglyceridemia, and diet-induced insulin resistance. Cell 2001 106:563-573.

129. Hallberg M, Morganstein DL, Kiskinis E, Shah K, Kralli A, Dilworth SM, White R, Parker MG, Christian M: A functional interaction between RIP140 and PGC-1alpha regulates the expression of the lipid droplet protein CIDEA. Mol Cell Biol 2008, 28:6785-6795.

130. Tseng YH, Kokkotou E, Schulz TJ, Huang TL, Winnay JN, Taniguchi CM, Tran TT, Suzuki R, Espinoza DO, Yamamoto Y, Ahrens MJ, Dudley AT, Norris AW, Kulkarni RN, Kahn CR: New role of bone morphogenetic protein 7 in brown adipogenesis and energy expenditure. Nature 2008, 454:1000-1004.

131. Beenken A, Mohammadi M: The FGF family: biology, pathophysiology and therapy. Nat Rev Drug Discov 2009, 8:235-253.

132. Wilson-Fritch L, Nicoloro S, Chouinard M, Lazar MA, Chui PC, Leszyk J, Straubhaar J, Czech MP, Corvera S: Mitochondrial remodeling in adipose tissue associated with obesity and treatment with rosiglitazone. J Clin Invest 2004, 114:1281-1289.

133. Bordicchia M, Liu D, Amri EZ, Ailhaud G, Dessi-Fulgheri P, Zhang C, Takahashi N, Sarzani R, Collins S: Cardiac natriuretic peptides act via p38 MAPK to induce the brown fat thermogenic program in mouse and human adipocytes. J Clin Invest 2012, 122:1022-1036.

134. Crisan M, Casteilla L, Lehr L, Carmona M, Paoloni-Giacobino A, Yap S, Sun B, Leger B, Logar A, Penicaud L, Schrauwen P, Cameron-Smith D, Russell AP, Péault B, Giacobino JP: A reservoir of brown adipocyte progenitors in human skeletal muscle. Stem Cells 2008, 26:2425-2433.

135. Elabd C, Chiellini C, Carmona M, Galitzky J, Cochet O, Petersen R, Penicaud L, Kristiansen K, Bouloumie A, Casteilla L, Dani C, Ailhaud G, Amri EZ: Human multipotent adipose-derived stem cells differentiate into functional brown adipocytes. Stem Cells 2009, 27:2753-2760.

136. Stanford-RJ-WM KI, Ding AN, Kristy T, Hitchcox KM, Dae Young J, Yong Jin L, Kim JK, Hirshman MF, Yu-Hua T, Goodyear LJ: Transplantation of Brown Adipose Tissue Exerts Beneficial Effects on Glucose Homeostasis. San Diego: American Diabetes Assocation, 71st Scientific Session; 2011.

137. David W, Piston SCG: Reversal of Type 1 Diabetes by Brown Adipose Tissue Transplant. San Diego: American Diabetes Assocation, 71st Scientific Session; 2011.

doi:10.1186/s40608-014-0013-5

Cite this article as: Reddy et al:: Brown adipose tissue: endocrine determinants of function and therapeutic manipulation as a novel treatment strategy for obesity. BMC Obesity 2014 1:13.

\section{Submit your next manuscript to BioMed Central and take full advantage of:}

- Convenient online submission

- Thorough peer review

- No space constraints or color figure charges

- Immediate publication on acceptance

- Inclusion in PubMed, CAS, Scopus and Google Scholar

- Research which is freely available for redistribution

Submit your manuscript at www.biomedcentral.com/submit
C Biomed Central 